\title{
Dialogue with the Future and the Political Prophesy in Nadine Gardiner's Novels
}

\author{
${ }^{1}$ Dan Chima Amadi and ${ }^{2}$ Amadi Appolonia Ifeyinwa \\ ${ }^{1,2}$ Directorate of General Studies, Federal University of Technology, Owerri, Imo State, Nigeria
}

\begin{abstract}
Nadine Gordimer appears ahead of South African politics when she denounced the nation's Apartheid policies and dehumanization of blacks. Both in campaigns and in her books, at home and abroad, her soul was with the black majority rule in South Africa. Although critics ruled that her political preoccupations were impinging on her art, Gordimer remained resolute. Critics were not comfortable with some of her contradictory roles like the moral stances in her novels and her atheistic disposition. Her inability to equate Zionism with Apartheid also unsettled her critics. But her post-Apartheid narratives show she is a century ahead of her detractors.
\end{abstract}

Key Words: Apartheid, Art, critics, novels, blacks

Critics who thought that Nadine Gordimer was finished with her post-Apartheid books were surprised with her publications of July's People and None To Accompany Me. For the two decade she campaigned against Apartheid lecturing in American Universities, the logical conclusion of his critics was that she would have nothing else to offer after the collapse of the policy.

There is no question about her position on morality, but critics see her atheistic disposition as ambivalent. Although she is in the vanguard for the emancipation of women, she does not believe feminism should lose focus. For instance in 1984, she refused to accept "shortlisting" of her book for the Orange Prize because the award admitted entries of only female writers. Thus, she believes that women should fight for space in a neutral and competitive environment if the oppression of women must stop.

This paper aspires to see the visionary and artistic aesthetics in the works of two of Nadine Gordime's novels, July's People and None to Accompany me and how her prophetic books have put her ahead of her critics.

She joined the African National Congress while it was still proscribed and hid ANC leaders in her home to enable them escape government arrest. She traveled extensively all over the world, campaigning against apartheid and its recriminating policies. Gordimer fought spiritedly against censorship and state control of information. She objected to her work being aired by the South African Broadcasting Corporation because it was maintained by the apartheid government. Nadine Gordimer has been very active in the fight against HIV/AIDS in South Africa. She was critical of the then South African president, Thabo Mbeki, for his handling of the AIDS matters in that country.

On the foreign scene, she carried her campaign against discrimination in the United States. With six other Nobel Prize winners, they wrote warning the US not to destabilize Cuba in 2005 when Fidel Castro took ill. Another seeming contradiction in her life was that Gordimer did not see Zionism as equivalent to apartheid when she urged her friend, Susan Sontag, not to accept an award from the Israeli government.

\section{Introduction}

Some critics believe some of Gordimer's positions are sometimes ambiguous. For instance, it is difficult to reconcile the moral stances in her books with her atheistic disposition, although she is not known to be very active in atheist organizations. Then, in 1998, she refused to accept "short listing" for the Orange prize because the award admitted entries of only female writers.

\section{Her Works}

Gordimer's preoccupation in her works deals with the issues of love and politics and the racial problem as they relate to South Africa. She does not believe political power is out to address the people's problem unless it is anchored on truth. Her characters are often ordinary people who traverse the difficult terrain of life by encountering arduous choices and appearing ambiguous. For her, the individual has a hand in shaping his destiny. She sees beliefs and organizations as obstacles that could be dismantled if need be. Her other works include A World of Strangers (1958), Occasion for Loving (1963), A Guest of Honour (1971), which won the James Tail Black Memorial Prize, The Conservationist (1974), The Late Bourgeois World (1966), The Burger's Daughter (1979), My Son's Story (1990) and A Sport of Nature (1987). 
Nadine Gordimer believes fiction is the best vehicle to transmit social truth, because all other forms impose certain censorship or strings that make whole-truth impossible. She argues in an interview in Transition, "Nothing I say in essays and articles will be as true as my fiction, - - - encompass all the things that go unsaid among other people and in yourself - - - There is always, subconsciously, some kind of self-censorship in non fiction". (qtd in Wastberg 7)

\section{July's People}

The story of July's People is a prophetic one about a bloody South African revolution which as it turned out did not happen. Instead, a black majority rule was instituted under Nelson Mandela in 1994. It is about July, a black South African house boy of fifteen years standing who hides his master BamfordSmales and his wife, Maureen Smales, and their three children from impending catastrophe. Bamford, an architect and his wife Maureen, a house wife and former dancer, are symbolized in role reversal, a delicate mix where Gordimer shows that whites could be nice and can reap rewards for good deeds. Gordimer evaluates this position in relationship with art, her own art:

Only through a writer's explorations could I have begun to discover the human dynamism of the place I was born to and the time it was to be enacted. Only in the prescient dimension of the imagination could I bring together what had been deliberately broken and fragmented; fit together the shapes of living experience, my own and that of others, without which a whole consciousness is not attainable. I had to be part of the transformation of my place in order for it to be known me. (Wastberg 8)

For her, the writer has to be guided by his conscience; it is this chord between him and his conscience that pulls his art. Thus, her fight against racism and discrimination against blacks is given fuller life in her fiction. And as a conscience of the society, she warns of the danger inherent in injustice. It is this pull that is the underlying premise in the art of July's People.

For Jennifer Gordon, the primary aim of Gordimer in the novel is to create or suggest a common language for South Africa, and that is the main objective of addressing the problem of language as a limiting factor in that country:

Through revealing presentations of the language of Bam and Maureen, Bam and July, Maureen and July, and other characters, meticulous portrayal of subtle changes in language during the course of these relationships and realistic discussions of the power and limitations of language, Gordimer shows that the creation of a "common language" will be necessary before any true understanding can develop between individuals in South Africa. (Gordon 1).

Opinions about what Gordimer has set out to do in the novel, July's People, vary. But what is indisputable is the author's good control of her art. The use of symbols is a regular feature in Gordimer's art. Issues of colour, the bakkie, sex and the war do not just mean what we ordinarily know of the words. They mean much more, sometimes used to attack ideas the author is set out to condemn. For instance the "yellow bakkie' (5)

"Was bought for pleasure, as some women are said to be made for pleasure. His wife pulled the face of tasting something that set her teeth on edge, when he brought it home. But he defended the dyed-blood jauntiness; yellow was cheerful, it repelled heat" (6).

Just as she opposed an 'only woman' literary prize award, she objects to females being only useful as object of pleasure.

Stephen Clinngman believes Gordimer plays to the gallery in her works, without a clear cut vision of the nature of the revolution which her art prescribes. But war which can defy manipulation and control is nobody's friend. Clingman's submission suggests deep misgiving:

In terms of the method in which its picture of revolution is presented, the novel is still candidly impressionistic. For there may be a way in which the novel is less interested in the future per se than in its unfolding in the present. (Thus the novel) may be the most deceptive, and deceptively simple, of all of Gordimer's novels, and perhaps less genuinely prophetic than, say The Conservationist. What the novel is apparently doing is projecting a vision into the future; but what it may be doing most decisively is in fact the reverse. For what appears to be a projection from the present into the future in the novel is from another point of view seeing the present through the eyes of the future. (Clinngman 1).

The regret of whites during the revolution, according to Gordimer, will be immense. The lack of communication in the Smales' home and a seeming bleak future steer them in the face:

They sickened at the appalling thought that they might find they had lived out their lives as they were, born white pariah dogs in a black continent. They joined political parties and 'contact' groups - - - They had thought of living, then, while they were young enough to cast off the blacks' rejection as well as white privilege, to make a life in another country. (8) 
In apparent fusion of Gordimer and her art, her atheistic attitude will obtrude from time to time: "It was a miracle; it was all a miracle: and one ought to have known, from the suffering of saints, that miracles are horror" (11).

If Bam is finding it difficult to communicate with his wife Maureen, this is not a problem for July, who Gordimer has firmly planted in his rural black folk language: "How they know I'm not driving? Everybody is known I'm fifteen years in town. I'm knowing plenty things". (13) Gordimer through Bam believes "The black man's English was too poor to speak his mind". (97) Maureen is more successful in her communication with July, Martha and other village women. Where Bam gets irritated, Maureen is patient to understand, having known that: "They could assume comprehension between them only if she kept away from even the most common place of abstractions; his was the English learned in kitchens, factories and mines. It was based on orders and responses, not the exchange of ideas or feelings" (96).

Gordimer might be hinting in her art that blacks are unprepared for the role reversal. July's inability to drop the word master, despite the protestations of Bam and Maureen suggests it: He used to have the habit of knocking at a door, asking, the master he say I can come in? And they had tried to train him to drop the "master" for the ubiquitously respectful "Sir". (52) The Smales try to make him drop the Simon degree term:

'The master Bam's not your master. Why do you pretend? Nobody's ever thought of you as anything but a grown man'. (71)

July's subservience knows no bounds. He sees himself as "their boy":

'You tell everybody you trust your good boy. You are good madam, you got good boy' (70).

Gordon submits that: "This is where language fails. Despite their many powers, words cannot perform the miracle of conversion that Bam and Maureen are looking for without a much greater change from outside" (106).

Because whites revel in opulence and blacks wallow in abject poverty, the gun powder to trigger the revolution has been ignited: 'They had to get out, they had to go. People are burning those houses. Those big houses! You can't imagine those houses. The whites are being killed in their houses. I've seen it-the whole thing just blow up, walls, roof' - (19).

The degeneration of the Smales reaches a feverish pitch with one of their children wiping his anus with a stone after defecating. Bam himself, hardly getting any relief from the sleeping arrangement does the same by asking how long the "toilet rolls will last?" (35). The holistic degeneration of the Smales begins for Sheil Roberts, as they enter July's house:

That the hut itself begins to have transformatory powers over its occupants is emphasized when, after the Smales family has enjoyed a rare dinner of roasted pig, and after Maureen and Bam make love, he wakes to see menstrual blood on his penis. He experiences a monetary horrifying hallucination that he has the pig's blood on him. This detail of bloody penis, an image of castration, suggests in part the return of the repressed to Bam's consciousness, the site of the return being, predictability, theunhomely hut in which he has recently "entered" his wife. (Roberts 81)

The war or revolution is symbolically unfair to whites, particularly, Maureen. Gordimer records her progressive diseased body: "she smelled bad between the legs" (9) and went to the level of using old rags during menstruation and when she sweats, she has a "cold-cat smell" (151). Now when she begins to seduce her own servant, every honour appears to have gone. This is not just a devaluation of white superiority; it symbolizes a decimation of white power and myth. Sheila Roberts thinks:

Maureen's final fording of the river in pursuit of the helicopter has been interpreted mythlogically as some sort of crossing of the Rubicon, or as a trope of rebirth. But I would posit that the moment of her posing sexually for July is also Rubiconal. Even if circumstances should change, she can never again revert to her old stable self as July's employer. (82).

On the other hand, one may be in a dilemma between Gordimer's political morality and the use of erotic love to drive home her point. Does Maureen think that since political power has failed erotic power should take over? Per Wastberg believes that:

Gordimer's territory has always been the border between private emotions and external forces. There are no neutral zones where people can rest unobserved. In a land of lies, everyone lives a double life. Only love, the erotic dimension, stands for a sort of liberty, the glimpse of a more truthful existence. Outside the lover's chamber, there is a society, greedy, immoral where empathy and responsibility for other whatever skin colour, are rare. Thus, every meeting becomes instrumental or abused. In many of her stories, Gordimer reminds us that the future South Africa is not only a question of votes for all but one that requires immense effort to create a civil sprit, allowing people to look each other in the eye. (7)

To tell her story, Gordimer makes the reader read beyond the lines. In and out of court, account, those often shunned by authors who are strongly restricted by puritan spirit come alive in her works. She lets her message posses whatever she wants to say, to let the scene tell its own story. The scene where Maureen goes to 
take her bath in the rain tells it better. Now a village woman, Maureen lives like any other village woman, white or black:

She went out. Night was close to her face. Rain sifted from the dark. She knew only where the door way was, to get back. She took off her shirt and got out of panties and jeans in one go, supporting herself against the streaming acid wall. Holding her clothing out of the mud, she let the rain pelt her lightly, face, breasts and back, then stream over her. She turned as if she were under a shower faucet. (48)

During the time of apartheid, disease and hunger ravaged the black community. Some of these diseases were peculiar to black children, hardly ever seen in whites. Gordimer recreates this scene in contradistinction to the children of the Smales who have now come to bear the disease: 'The children had begun to cough in their sleep for the last one hour or so- the same cough that one always hears from black children'.(50)In a sense, Gordimer's play with the fire image is symbolic. It is a symbol of crisis, but also a source of life. Fire reinvents primordial existence. During the period of apartheid, it was the cause of death, issuing deadly blows from the barrels of guns that maimed and killed. But after a two - day rain, the Smales long for it:

The hearth-fire that filled the hut with smoke was the centre of being; children, fowls, dogs, kittens came as near to it as the hierarchy of their existence allowed. The war with that food brought blood chafing into life-came from it, where the clickers of wood, transparent with heart, made the porridge bubble vigour. Bam and Maureen had longed for cigarettes, for a drink of wine or spirits, their children had craved for sweet things; but in the days of the rain, the small fire they never let die satisfied all wants. (58)

The co-habitation, as it is between July's people and the Smales, is somewhat emblematic. As it continues to engender role reversal, July learning how to drive and Bam learning how to chop wood. Both stick to the new vocation with zeal and dedication and not letting the other to assist in the new chosen field: "You shouldn't bother. I've told you. I can chop my own wood. You mustn't do it" (59)

Bam insists. July insists on driving without a license because of the new political structure now in place:

"Who's going to catch me? The white policeman is run away when the black soldiers come that time. Sometime they take him. I don't know - - - No one there can ask me, where is my license. Even my pass, no one can ask me anymore. It is finished". (59)

July's manner of speaking is in defiance of the existing law and order. Is black majority rule all about lawlessness as the present situation in South Africa shows - rape, armed robbery and killings? Gordimer's hint is prophetic as indeed most aspects of the novel are except the bloody revolution that never takes place.

Gordimer's theory of equality of the races is dependent on equal emotional satisfaction and deprivation in the same degree. She spurns any other consideration based on colour or hair:

There was fear and danger in considering this emotional absolute as open in any way; the brainweighers, the claimants of divine authority to distinguish powers of moral discernment from the degree of frizz in hair and conceptual ability from the relative thickness of lips-they were vigilant to pounce upon anything that could be twisted to give them credence intimate relationships arrived at? Who decided? (92)

In the same way, identifying grace and beauty when they are observed, Gordimer openly acknowledges black beauty, not based on colour or artifice but based on clearly natural endowment:

Maureen laughed back at her, at her small pretty tight-drawn face whose blackness was closed quality acting upon it from within rather than a matter of pigment. Why should the white woman be ashamed to be seen in her weakness, blemishes, as she saw the other woman's. (92)

Beauty when seen ought to be complimented instead of deriding it based on one prejudice or the other. The high point of the revolution is that whites are now the endangered specie. Instead of being the predator, they have now turned and become the prey. Gordimer with these hints on the uncertainties of life, its inequalities and unpredictability: 'Why? D' you think someone might see me? But the local people know we're here, of course they know. Why? There's much more risk when Bam goes out and shoots. When you drive around in that yellow thing - - are you afraid -'(97)

At a stage it has become a risk to keep whites in one's home. Like the author did herself for the African National Congress (ANC) members during the apartheid days, July is in danger of keeping the Smales in his house. He has to take permission from the local chief, to avoid black reprisals:

He know who it is we - He send someone ask who I'm keep in my house. Someone say you must come there to the Chief's place. I must show him. Always when people is coming somewhere, they must go to the Chief, ask him? -

Ask him what? -

Ask him nice, they can stay in his village. (100)

Gordimer uses the opportunity to show the true allegiance of traditional African structure over the alien structure which the Western political structure represents. That July is eager to obey the Chief and break the laws of the government by driving without license shows that there is more allegiance to the former: 
-Yes I'm say that. My place is here. But all people here, all villages, it's the Chief's. If he's sending someone ask me this or this, I must do. Isn't it? If he's saying I must come, I must come. That is our law. (100)

Bam's loss of authority and degeneration reachesits peak when he goes to the bush to defecate. The smell he leaves behind which showers and bath have always kept away becomes now noticeable. Suddenly a body which Maureen has caressed with her tongue becomes loathsome, repugnant and disgusting. For the natives, heath-fire becomes the perfume to drive away body odour. By centralizing it, they make fire a part of life and a soothing balm. In authorial intrusion, Gordimer makes a case: "only those still thinking as if they were living with bathrooms en suite would have decided, civilized, the custom was unhygienic and too hot" (103).

With a little pride still left, the Smales question the Chief's right over their stay in an African Kingdom, his own kingdom. Obviously they have forgotten they are living in an age that is fast fading, that has no bearing with the present:

What business of the Chief to tell them where? He had not asked them to come here. A wide arc of the hand: plenty place to go. And this was not their custom, but the civilized one; when a white farmer sold up, or died, the next owner would simply say to the black labourer living and working on the land, born there: go. (104)

Gordimer makes bold to challenge the age - long white supremacy. How will the white feel if they are visited with such injustice, she seems to ask? The visit of the Smales to the Chief's house turns out to be an enlightening one. The Chief wants to be educated on everything possible under the sun: visit with the pope, interrogation with the secret police, the black-white relationship, with July remaining the bridge between the Chief and the Smales:

What's he say? -

He's say he can't believe that; white people are not shooting, the government is not killing those men? Always the white men got the guns, those tanks, aeroplanes. Long time. Even from fourteen - eighteen King George war. Even from Smutes and Vorster time. The white men can't run away. No. Why they run away? (117).

July also admits that the Chief has respect and influence but in the context of the modern world, even in black majority rule, he is powerless. He is a toothless bulldog whose influence is fast giving way to modern governmental structure. In a sense, under both systems of apartheid and multi-racial society, the Chief's future is doomed because he has no money and cannot stand on the way of the black majority rule:

He is our Chief, but he doesn't fight when the white people tell him he must do what they want-they want. Now can he fight when the black soldiers come, they say do this or this. How can he fight? He is poor man. He is Chief but poor man, he has got money if they come over here, those what you call it, the people from Soweto they bring them, they eat his mealier, they hungry, kill a cow - what he's going to do? Can't do nothing. Talking, talking - (122 - 123)

July is like Petrus in Disgrace by J.M. Coetzee; a black wily fox who is so worldly wise that he is an expert in upstaging unsuspecting whites. Bam could read deeper the nature of July but because he has made so deep impression on Maureen: "She wouldn't have Bam say anything to him, offend his pride, he was so highly intelligent in other ways" (99).

July defends Victor as Petrus defends the boy, Pollux that joins other boys to rape Lucy. Between Petrus and July there is little difference. Both are servants who later assume the role of masters; both are ambitious; both are go - betweens between blacks and whites; and both wish to continue to protect black interest. In terms of education they are a little more than illiterates and they have limited language power but they are very crafty.

The baseline then is a situation where two white writers have deep knowledge of characters they are describing and who shoot them out as products of racism and fruits of many years of repression, JoahSilbur's review is apt in this regard:

Gordimer's novel is an intense look at a network of power relations: black to white, servant to master, male to female, child to parent - and the enormous changes through in all allegiances once power shifts utterly. For all the extremities of the situation it chronicles and the suspense - drama of its plot, it is a very subtle book spare, careful, and instructive. (Silbur 1)

Opinion varies as to the success of the author in July's People. The novel is often compared with Daniel Defoe's Robinson Crusoe. What is however clear is Gordimer's role as a champion of the oppressed.

\section{None To Accompany Me}

Gordimer's eleventh novel - None To Accompany Me is her most complex novel in which she displays exceptional skills. The story is about Vera Stark, a white civil rights lawyer, her married life, infidelities, and the violence in South Africa after the collapse of Apartheid and the corruption, political rivalries and acute housing problems that engulfed that nation. The novel is also about Vera Stark's increasing evolution from a naïve house 
wife to a highly assertive liberal lawyer who chooses to pitch her tent with the plight of blacks at the end of the major changes in South Africa.

Sensual and somewhat inconsiderate in the matters of love and marriage, Vera's role as mother and lover is progressively geared towards self protection. It is Gordimer's real throw to the lot of the feminist. Vera is content to throw out her handsome husband, Bennet, to the streets homeless despite the sacrifices he makes on her account. The house she inherited from her first marriage after a divorce is sold off when Bennet goes on a visit to see their son, Ivan, a London banker. Vera's answer to the action when her daughter enquires why is:"Because I cannot live with someone who cannot live without me" (310). Her daughter, Annie, a gay South African doctor, is aghast by her mother's insensitivity.

In a parallel characterization, Gordimer creates Didymus and his wife Sibongile (Sally) who has just returned from abroad after the inauguration of the new black majority government with their beautiful daughter, Mpho. Didymus is sidelined but Sibongile is rehabilitated through a high profile job as deputy director of the movement's regional redeployment programme for returnees. Later she is elected as a member of the central executive in the post-apartheid movement. Tashiko Sakamoto believes that

Nadine Gordimer'sNone to Accompany Me (1994) presents a definite shift of perspective in the way her work represents Black female characters. Here there is more concern than ever with the empowerment of Black Women in politics. The novel explores both Black and White women's empowerment within South Africa's national transformation during the period of dramatic change in political power from white dominance to the first democratically elected government. (1)

As a writer, Gordimer is a hero of sorts, for trailing the dangerous terrain by opposing apartheid. She finds it difficult to understand the hypocrisy of white conservatives who preach race purity. In an interview with Dwight Garner, she backs her books thus:

Well, you know, in the fundamentalist milieu of the Afrikaners, there was a sense that they were a chosen people, that they were bringing civilization to the blacks. And look at the whole race purity theory. Is that not one of a chosen people? Why would it be diminishing the race to have a mixture of blood? Why would it be that the dilution of the blood would be such a terrible thing? (5)

None to Accompany Me reveals a pagination of self in the story. It could lead to consistent evaluation of self which will lead to the question: Is justice all about self survival? Vera questions her daughter when she asks her why selling the house should ever be contemplated: "When someone gives you so much power over himself, he makes you a tyrant" (310), she replies. But Vera has never really been a fair person, cheating on her husband in her matrimonial home when he is busy fighting at war and getting the same house in settlement after divorce. She later submits to Otto in shameful sexual glorification. But fate has equally been fair to Bennet. A war love rat ought to pay for his crimes at peace time.

Gordimer had said: "I shall never write an autobiography", to a journalist and she repeated it to her interviewer, Dwight Garner (7). But she has been consistently compared with James Frey as a writer who fabricated parts of her lives in order to sell her books. Even her biographer, Ronald Suresh Roberts, parted ways with Gordimer because he claimed that Gordimer's essay: "A South African Childhood", was not entirely autobiographical. Gordimer accused her biographer of making certain revelations which she saw as a "breach of confidence" and she renounced the book which he later published without her authorization.

Gordimer's elevation of black womanhood in None To Accompany Me is significant. Her making SibongileMagoma prominent at the expense of her husband, Didymus, has been hailed as a departure from her stance in her earlier novels. She appears coming to term with the idea that the total liberation of South Africa cannot be an all male affair. Black woman's struggle is a fire in the cause. Sibongile believes that home politics is central to her self liberation and that of other African women.

While Coetzee has been criticized for lack of enough political commitment, Gordimer is seen as running a crusade, chronicling black suffering for which she has never suffered. Garan Holcombe rises in her defense thus:

Gordimer has been criticized for writing from a position of privilege, of suffering from what she has described as "the languid evasions of moral guilt": this is unfair. You are not denied a voice and a perspective simply because you have not suffered for your skin colour. Furthermore, this form of criticism negates Gordimer's position as a staunch defender of a free South Africa, and of her right to be a liberal witness to her country's tragedies. Some it would seem are frustrated that the writing career of Nadine Gordimer has outlived Apartheid. In the mid 1990s several critics questioned whether there was a place for her after the fall of the regime. These were the sort of people who saw her as a 'protest' writer, whose work was done the moment Nelson Mandela was elected. This is an absurd attempt to reduce Gordimer as a writer. (3)

Recent publications by Gordimer have proved her critics wrong. She has demonstrated to the astonishment of her critics that she is a writer for all seasons, whose career spans ages, political eras and across generations. With The House Gun (1998), The Pickup (2001) and Get a Life (2005), all written after the death of her partner show that she is not yet done. Get a Life is the story of Bannerman who returned to her parent's 
home after becoming radioactive. It is an attempt by Gordimer to x-ray the evils of the South African ecosystem in the face of rising exploitation of the environment. The Pickup is the story of a privileged daughter of an investment banker and an Arab - African mechanic, while The House Gun tackles the emotional catharsis of a white couple whose son commits murder and runs to a black lawyer for defense. The story of Vera Stark is however unique as Gordimerherself observes:

Vera Stark's image looms large in the foundation building and she is almost indispensable. When Oupa is studying for his law examination, she is the resource person, the clearing house in his journey to the Promised Land,

She was the figure of the school - mistress missing in his lonely-self education, she was the abstract image of authority that, resented all your life or not, you had to turn to in your powerlessness. (15)

On the contrary, Bennett Stark has been anything but a success in his own chosen field. He carves wood and models clay but even then recognition seems long in coming. He falls back on his English degree which he had earned when he has not decided on a career. Like David Lurie, his success in this area is scanty. Gordimer's opinion of him is poor despite his good looks: 'From the point of view of advancement in the academic community it's a bad sign to have some advantage that is simply a gift of nature, not earned and not attainable for others by any amount of hard work, lobbying or today'. (19)

Vera Stark is not in the mould of her creator who abhors injustice because it offends her sense of justice. Gordimer uses Vera to state a case of justice for its own case which later explains the life she lives, her immorality and insensitivity. For instance:

She went to work at the Foundation, not out of white guilt people talked about, but out of a need to take up, to balance on her own two feet the time and place to which, by birth, she understood she had no choice but to belong. This need must have been growing unheeded - seed that by a bird and germinating, sprouting, beside a cultivated tree - climbing the branches of passionate domesticity. (21)

Thus, Vera Stark is a well thought out character, carefully created to nib at the population and throw off the guilt of the past. It is for this reason that Garan Holcombe asserts:

Gordimer explores against the growth of black consciousness. She examines the complexity of white privilege, inviting us to see the weakness of the liberal response to Apartheid. She also investigates its attempts at self - justification and finds that even in benevolence, there can be an ugly egotism. (3)

Gordimer's campaign against Apartheid has been steady and fierce. But this fight sometimes assumes the nature of a crusade. Her critics feel she is too much into the sociological to the detriment of her art. Gordimer's novel that is particularly referred to is My Son's Story. Yet, a careful look at most of her novels reveals this tendency. Clive Barnett supports this point:

Gordimer's novel is judged to be too weighed down by its author's urge to write explicitly about politics in South Africa. It's a good read and good journalism. It informs and explains. But it's too banal and too explicit to be good art'. Gordimer's political urges are seen to impinge upon the quality of the novel's writing. A dualism is set up in this sort of evaluation, between the novels which escape the murky traps of a society saturated with political significance, and novels which apparently succeed in rendering political reality but are, by this very token, condemned to a lesser aesthetic judgment. (291)

Part of Gordimer's greatness is to create a character in a distinguished way so that when he or she begins to fall, the audience can identify with him/her. Affectation and empathy forever intermingle in her art, always playing themselves out in the life of the characters. For instance, Mpho, the daughter of Didymus and Sibongile has to be appealing so that when she gets pregnant and goes for abortion, we read more resentment into Vera's grandson's flirtations with her. Gordimer describes that: "The Magoma daughter was a sixteen-yearold beauty of the kind created by the cross-pollination of history" (49). This is a suspenseful creation and a demonstration of a skill which makes the art of Shakespeare great:

This school girl combined the style of Vogue with the assertion of Africa. She was a mutation achieving happy appropriation of the aesthetics of opposition species. She exposed the exaggeratedly long legs that seem to have been created by natural endowment to the specification of Western standards of luxury, along with the elongated chassis of custom-built cars. (49)

The twenty first century art has been marked by 'polished' liberalism towards sex by the world leading writers - Coetzee, Gordimer, Morrison etc writing in English. In their art, while sex is given prominence because it occupies a significant place in the life of mankind, care has been taken to condemn sexual acts that have been suggestive of immorality. Bennet snatches Vera from her husband but she betrays him even while still living with him. Vera's betrayal is Gordimer's way of saying that such women should not be trusted. She calls her a bitch a number of times to voice her disapproval: 'Bitch, greeted her face in the mirror and next day she went back to one twenty - one. There she felt it was her lover would accept that a woman like her could enjoy making love with another man? With her husband?' (68) 
Injustice breeds injustice. That is what Apartheid has done. Bennet is stabbed in the back as he has stabbed the first husband of Vera. Although he does not know and never suspects, her final act towards the end of the novel, turning him to the streets, is a well deserved revenge. This time he knows. Vera's last love making with Otto Abarlanel shows the place of his betrayal and the morality level of the lovers:

There was no appropriate place for that curious passion to be enacted, and so it happened in the kitchen, she took him in through the aperture of clothes pulled out of the way, standing up where they had risen from the kitchen table, they were clutched like a pillar shaking in an earth tremor, and never before or after in her life was she, in her turn, transformed, and fused with a man in such blazing sensation. That was the day and place of betrayal of Ben, Bennet, the chosen man (70)

In his letter to his mother, Ivan tells Vera: "We somehow learned from you about emotion, you can't fake love" (90) when he switches like her from his wife to "a Hungarian redhead" (90).He says, "If it's gone, its gone" (90). Ivan does not understand that it is nature at work. His mother is a little better than a whore and she gives birth to a gay South African doctor and himself, a London banker divorcee.

Annie brings her Lesbian partner into her father's house as a man would bring his wife to see his parents. She even reveals their marriage intentions. In the same house, secured through adultery, husband and wife make love in one room while their daughter, Annie makes love to another woman in the next room. The debauchery has no limit: 'They were making love the way a man and woman do, in this house where, on the other side of a wall, two women lay enlaced. The awareness became a kind of excitement, a defiance for her, an assertion for him'. (227) Gordimer's description is not without a cause. Human weakness can be found in both black and white. It is an invitation to race theorists, especially those interested in the 'purity' of blood to come and provide answers. She does not make excuses for the aggression of the modern woman, who hides under sexual perversity to inflict embarrassment on the society. Gordimer carefully shows that Vera's depravity is a self creation, an inclination to always throw caution to the wind. At a dinner, Vera bares it all:

Poor thing; she comes clip-clopping into the ladies' room on high-heeled hooves and behind the door there is the noisy stream of her urine falling, she's even taught herself to piss boldly as a man. Or perhaps that's wronging her-she comes out and smiles, my God I was bursting, hey, sorry. (107)

Vera is not just promiscuous; she is given to too much wine. It is difficult to establish Vera's morality even when it concerns her children. At a time when Annie needs the big stick to rouse her into consciousness, from the depravity of lesbianism, she shamelessly sits on the fence, when the child needs the truth and parental disapproval:

Tell me. We disgust you-Lou and I-

Of course you don't -

No 'of course' about it, Tell me. -

No disgust -

'So long as I'm happy', mnh? - What all the parents deprived of grand childrenswallow bravely and say.

It's just the penis. No - I don't disapprove. I don't consider what you do is wrong. I have to say it. I regret for you-no penis (160)

Nothing is important to Vera in a man-woman relationship except sexual satisfaction. And when Annie asks:

"What about Ivan? With the penis, and the grandchildren, it still didn't work out -" (160),

Vera has nothing to say except

"Al, it doesn't solve everything, I'll admit" (160)

Gordimer through this discourse is inviting every race to see for itself. The quality of the mind does not depend on colour. Like J.M. Coetzee's Disgrace, Lucy the daughter of David Lurie is equally morally depraved. Gordimer and Coetzee are preaching the same thing. Evil is not a colour thing, it is a cancer in man, in both black and white.

Gordimer's sense of justice knows no bound. Just as the heat is turned on blacks at the time of Apartheid, which is condemnable, it is also unjust to practices violence during the post Apartheid era. The bloodbath in Odenville, the rape, burning and maiming are not issues to cheer about. Vera is only echoing Gordimer's deep seated disapproval:

When I heard that Apla man on the radio saying there is outrage only because this time whites were killed, I agreed with him. He shocked people because they see him as racist, but what he said is more than fact, Zeph, it's true, it's right inside, deep in whites who own newspapers and the TV and radio stations. But we can't say it because we're not racist, we can't say it because we have to demonstrate we don't stereotype, we don't use racial categories in the worth of human life. Killings are killings. Death is death. Blood and wine mix. All we can produce is this cover-up. (152) 
For those who believe in judgment, in fairness, there should be no shedding of blood. Nothing justifies murder, not even for revenge and certainly not a cause to atone for all the ills of Apartheid in the past.

The relationship between Zeph and Vera is deep and complex and needs some comment. ZephRapulana is an ambitious, politically sagacious and financially sound black lawyer in the employ of the foundation. Although he is soft spoken, he has come to be part of that engine room that moves the foundation. Vera is powerfully drawn to him although sex has no place in their relationship. Yet: "Vera had never before felt - it was more than drawn to - involved in the being of a man to whom she knew no sexual pull" (123)

"At the same time, she was beginning to have an inkling that her sense of connection with this man was that she had something to learn from him, as all unbelievers secretly hope to appropriate a value without adopting a faith"(154)

It is to Zeph's house that Vera turns when she sells off her only house. It is difficult to dismiss sexual interest in the act although Vera claims it is without such entanglements:

"It was as if, in the common place nature of their continuing contact through the foundation, they belonged together as a single sex, a reconciliation of all each had experienced, he as a man, she as a woman". (123)

The experiment between Zeph and Vera is a continuation of Gordimer's credo, of a universal bond between all mankind; a world where feelings should play a dominant role and where sexual satisfaction could be reached from all races.

A dominant theme in None to Accompany Me is the emancipation of black and white women. This is particularly noticeable in Sibongile, Mpho, Vera and even Oupa's wife in the village. Sibongile's rise to power blunts the political edges of her husband, Didymus. Gordimer tries to compare the efforts of Oupa's wife who labours to fulfill her role as a house wife whose husband is away, and Sibongile who strives hard to maintain her visibility in the new political arrangement. Oupa's wife complements her husband's energies, without whose effort he would have found it difficult to concentrate. She is thus a part of the struggle in the new dispensation in a strong way.

Gordimer, it seems, has thus reacted to an earlier criticism that her works sidelined black women and made them invisible. She has been fair to white women in this regard, although they are seen as appendages to black men in the struggle for emancipation. Even Mpho tries to break away from the clutches of her parents. Gordimer sees her as a "cross-pollination" of history. She speaks "a perky London English" and she is: "a style of beauty that comes out of the clash between domination and resistance" (None 49). Mpho is a symbol of the upcoming generation, trapped between contemporary historical intersection and dialogues with the future. Toshiko Sakamoto argues that in the emancipation of women in None to Accompany Me:

Gordimer parallels the reversal of ascendancy and the consequential withdrawal of sexual attraction from the husband to his wife who has become a revolutionary without his knowledge. Sibongile'sfeminity and her sexual appeal to Didymus are also overshadowed by her political advancement: "This body beside him invaded the whole bed, lolled against him. His own body felt no sign of desire for it". Although Sonny and Didymus are free from the common male opposition to or reluctance in women's political activism, there are real delicate problems and new dilemmas for them within the new conception of women and their empowerment. The novel thus explores pressures and anxieties created when women are empowered and addresses the question of how men may reconcile with the re-organization of gender relations occasioned with the politicization of women. (3)

Gordimer is as much astonished as the world in the level of violence going on in South Africa despite a smooth transition to black majority rule. She could not find answers to it and she stays behind Lou, the partner of Annie to express it:

I don't suppose the fact that we were blacks and whites would make much difference if the object is to create terror. Stop negotiations. But think of the international hullabaloo if the UN representative were to have been killed. Now that would have been something to wake up the outside world to this government's failure to deal with violence. (150)

The heart of Gordimer is in universal justice, one that is not dependent on either whites or blacks. If Botha could be criticized for fostering violence and discrimination, will President Zuma be applauded for the flowering of violence, rape, arson and robberies in South Africa?

In None to Accompany Me, Gordimer sees culture crisis as one of the aftermaths of the white-black interaction in South Africa. A character like Mpho is a victim of this relationship. Completely alienated from her cultural roots, Mpho finds out that she cannot escape her roots despite her cultural hybridization. Sexual liberalism and youthfulness are the greatest compelling drive. She plunges into Oupa after other spateful affairs and in falling in love assumes that sincerity is the key word. Oupa is married with kids and still has his eyes wide open. When Vera asks him: "So you love her. You think you were in love with her -" (175), Oupa's answer astonishes even Vera: 
"When I say I don't know - - - such a kid, the time when I might have a girl-friend like that, I was inside, those young years. But also she's seen, she knows, so many things I never have - London and Europe and so on - - - sometimes she even laughs at me, the things I don't know about. In one way she's too young, and in another way she's ahead of me. So I don't suppose we could ever get it right" (176)

By consenting to abortion, the parents of Mpho are showing that they are no longer in tune with their roots. Life in exile and Western culture has ensured that they could terminate life to save their face. Only Mpho'sgrand mother in Alexandra is still with her roots. She does not consent to abortion:

"Our people don't do this thing. Our children are a blessing. We are not white people. Didymus is my son. Mpho is my child. This child will be my child. I will look after the child here, in my house. I have told Mpho". (187)

Mpho submits herself to the abortion plan in a way that suggests that the old order is gone. It is like Africa, the old Africa giving way to the Africa of the future. But the act will always hunt Mpho and tear her psyche. Even Vera Stark will not like her grandson Adam to be in love with such a girl. Thus, the kind of future Mpho will be dialoguing with will be one with moral crisis, one that is not completely acceptable to whites and blacks.

\section{Conclusion}

The marriage in the future South Africa in Gordimer's opinion is not going to be what it used to be with their parents.

In conclusion, the opinion of Nadine Gordimer is that marriage in the future South Africa will not be the same again with the present. As the old order has changed, so will South Africans expect moral and ethical crisis.

\section{References}

[1]. Barnett, Clive. "Constructions of Apartheid in the International Reception of the Novels of J.M. Coetzee". Journal of Southern African Studies. 25 November, (2), 1999. 287-301

[2]. Clingman, Stephen. July's People (Critical Overview) fromAnwers.com.http://www.answers.com/topic/July's people-novel-6 9/10/2008 4:29p.m Garner, Dwight. "The Conscience of South Africa Talks about Her Country's New Racial Order" The Salon Interview. File///E/salon $\% 20 \% 20 \%$ the $\% 20$ salon $\% 20$ Interview $\% 20$ Nadine $\% 20$

[3]. Gordimer, Nadine."English Language, Literature and Politics in South Africa". Aspect of South African Literature. Ed Christopher Heywood. (London, New York: Heinemann, 1976). 99-120

[4]. - July's People.( New York: The Viking Press, 1981).

[5]. “The Idea of Gardening". The New York Review. 2 February, 1984. 3-6

[6]. None to Accompany Me.( London: Penguin Books, 1994).

[7]. "The Novel and the Nation in South Africa".

[8]. Times Literary Supplement, August 11(1961).

[9]. "English Language Literature and Politics in South Africa" in Christopher Heywood(Ed) Aspects of South African Literature. (London: Heinemann Educational Books ,1979).

[10]. Gordon, Eugene. "Outstanding Negro Newspapers" Opportunity. (Dec.1924).

[11]. Roberts, Sheila. "Sites of Paranoia and Taboo: Lessing's

[12]. The Grass Is Singing and Gordimer's July's People”. Research in African Literature. 24(3), 1993.73-85

[13]. Wastberg, Per. "Nadine Gordimer and the South African

[14]. Experience". http://nobel prize.Org./nobel prizes /literature/article/Wastberg/index.Html 26th April, 2001 - 11/01/01/02:10:42AM. 